\title{
deformações da interioridade:
}

\section{MARCAS EXPRESSIONISTAS EM O LUSTRE, DE CLARICE LISPECTOR}

Deformations of interiority: expressionist marks in O lustre, by Clarice Lispector

\section{Mariângela Alonso ${ }^{1}$}

Resumo: A arte expressionista realiza-se por meio da tendência à deformação dos aspectos naturais da realidade como forma de traduzir de modo subjetivo o indivíduo e o cenário que o cerca, reivindicando, assim, a presença dos sentimentos em oposição à representação objetiva. As questões suscitadas pela estética expressionista não deixaram de se fazer sentir na escrita de O lustre (1946), segundo romance de Clarice Lispector, cujas confluências remetem a traços do grotesco. O plano discursivo desta narrativa revelase cruzado, demorado e interrompido a todo o momento por reflexões e miragens da personagem Virgínia. Nesse contexto, o objetivo deste artigo é focalizar marcas da estética expressionista como força dissonante da ficção de Clarice Lispector.

Palavras-chave: Expressionismo; grotesco; Clarice Lispector; O lustre.

Abstract: Expressionist art takes place through the tendency to deformation of the natural aspects of reality as a way of subjectively translating the individual and the surrounding landscape, thus claiming the presence of the feelings as opposed to the objective representation. The issues raised by expressionist aesthetics were not lost on the writing of Clarice Lispector's $O$ lustre (1946), whose confluences refer to grotesque features. The discursive plan of this narrative reveals itself crossed, delayed and interrupted at any moment by reflections and mirages of the personage Virgínia. In this context, the aim of this article is to focus on expressionist aesthetics as a dissonant force in the fiction of Clarice Lispector.

Keywords: Expressionism; grotesque; Clarice Lispector; O lustre.

$1 \quad$ Pós-doutora em Literatura Brasileira pela USP.

*Artigo recebido em 13/07/2019 e aprovado para publicação em 18/09/2019. 


\section{por uma estética da deformação}

O Expressionismo foi um dos movimentos estéticos mais relevantes e heterogêneos do século $X X_{i}$ desenvolveu-se inicialmente na pintura e repercutiu transversalmente em outras linguagens artísticas, como: teatro, música, dança, fotografia, abrangendo também a moda e os meios de comunicação. Seus adeptos utilizavam a revelação e representação do mundo subjetivo, desconhecido e alheio a toda e qualquer realidade centrada na razão. O movimento transmitia uma reação a toda estética positivista relacionada ao Impressionismo e ao Naturalismo, escorando-se numa expressão subjetiva e autêntica. Essa expressão lançava mão de mecanismos ligados ao olhar interior do artista para a obra e para o mundo. Provindos da herança romântica, os artistas expressionistas partilhavam também inquietações e questionamentos assinalados pela experiência estética de fin de siècle que os antecedeu.

Atingidos por essa nova forma de encarar a realidade, tais artistas buscavam algo puro e concreto, na tentativa de extrair do mundo uma estrutura interna instigante e enigmática. Nesse sentido, a arte expressionista realiza-se por meio da tendência à deformação das formas naturais da realidade como forma de traduzir de modo subjetivo o indivíduo e o cenário que o cerca, reivindicando, assim, a presença dos sentimentos e expressividade em oposição à mera representação objetiva da realidade.

Esta definição encontra ressonâncias na pintura, oferecendo à expressão artística um sentido de arte que convida não à mera cópia, mas à produção inusitada e secreta do cotidiano. Nesse sentido, destacam-se as telas do norueguês Edward Munch (1863-1944), um dos precursores do Expressionismo, cujas obras trazem "criaturas cercadas de um ar pesado", movendo-se numa "atmosfera espiritual" (BRILL, 2002, p. 395). Destarte, sua temática é cercada pela relação enigmática do homem, na natureza, com tipo efêmeros e sentimentos demoníacos e solitários. Como podemos observar na tela "Cinzas" (1894): 


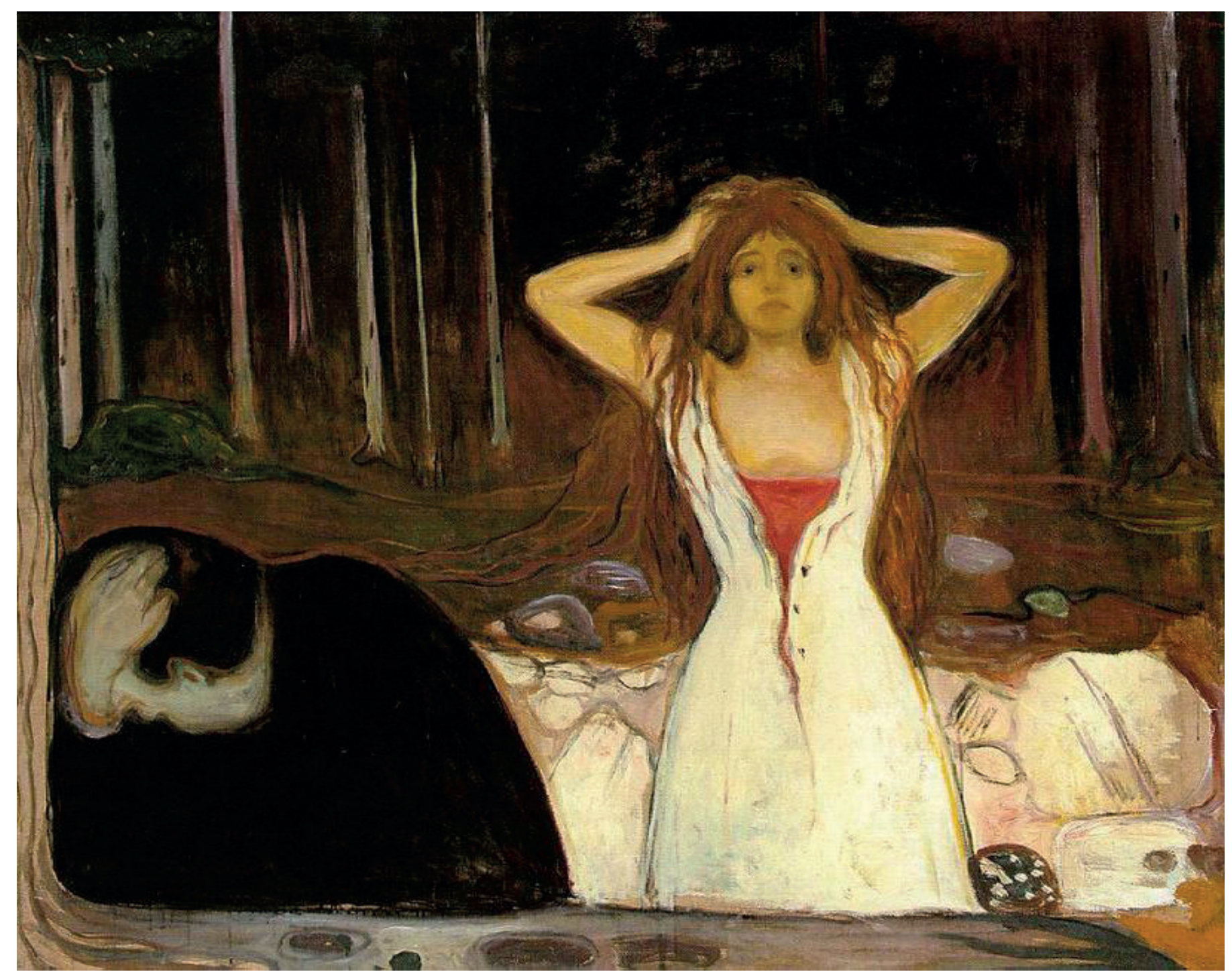

Cinzas (1894), de Edvard Munch. Óleo sobre tela, $120 \mathrm{~cm} \times 141 \mathrm{~cm}$. Galeria Nacional, Oslo, Noruega.

Cinzas exibe um campo de emoções pessimistas presentes na relação entre um homem e uma mulher. A partir do fundo escuro dos troncos de árvores delgadas, o mundo surge como um espaço absolutamente incompreensível, traduzido pelo abandono e solidão das figuras. O olhar perdido da mulher e seu gesto com os braços ressaltam que ela está entregue à própria estranheza e ao desespero, o que acentua a dramaticidade da cena. Sua roupa clara e semiaberta opõe-se ao fundo escuro, denunciando algo que ocorreu. Do mesmo modo, o homem afastado à esquerda da tela revela a desolação e imersão em si mesmo. O casal encontra-se rodeado por uma floresta sombria, que contrasta com o colorido e a luz refletidos nos longos cabelos ruivos da figura feminina. Há contraste também nas formas, com traços que repercutem tensões, por meio de linhas curvas, cores escuras e brilhantes ao mesmo tempo. 
De acordo com as informações contidas no site do Museu Nacional de Oslo, Norvega, o pintor explicou o título da obra em uma versão litográfica a partir da frase: "I felt our love lying on the earth like a heap of ash" ${ }^{2}$. A frase denota claramente a atmosfera pessimista e deformada presente na relação fracassada entre o casal. De maneira geral, Munch mostra o fim do relacionamento dos amantes por meio de "atração e repulsa, separação dolorosa - o indivíduo em sua solidão" (BRILL, 2002, p. 395). Nessa obra, a estranheza torna-se um importante pressuposto para a criação artística.

No campo literário, há um certo "espírito de negação" (FLEISCHER, 2002, p. 146) e pluralidade de motivos, sobretudo na produção localizada no período efervescente dos anos de 1910 a 1925, que se caracteriza pela busca de novas soluções e reorientações poéticas. $\mathrm{Na}$ arte narrativa expressionista, a linguagemémarcada pelo procedimento de "redução ao essencial", tornandose "eruptiva, intensa, precisa e concisa", ao mesmo tempo em que extravasa "em hipérboles retóricas que, por sua vez, também refletem a rejeição das formas estereotipadas, radicadas num repertório tradicional" (Ibid., p. 146). Trata-se de uma estética dissonante, em que a dimensão harmônica é anulada pelo insólito de uma realidade deformada e fragmentada. Via de regra, as narrativas tencionavam exibir tanto a realidade em seu movimento quanto a totalidade das relações sociais e individuais de uma época, para revelar não apenas a superfície imediata dos fatos, mas seu âmago, formado por um elo entre o mundo, a sociedade e o sujeito.

Como exemplo destes procedimentos, é possível citar as obras de Carl Einstein (1885-1940) e Alfred Döblin (1878-1957). O primeiro rejeitava o romance descritivo, concebendo-o como algo extremamente ultrapassado. Ao defender a presença viva de um aspecto reflexivo na narrativa, Einstein apresentava a consciência dos personagens por meio das reflexões dos narradores, transcendendo, assim, o mundo como objeto: "parecia-lhe absurdo reproduzir um acontecimento com seus pressupostos e suas consequências, uma vez que toda e qualquer fundamentação baseada nos preceitos da causalidade é sempre provisória" (FLEISCHER, 2002, p. 153). Döblin, porsua vez, suprimia a presença mediadora do narrador, elegendo um foco narrativo objetivo, com descrições puras e simples, de modo a eliminar

2 Tradução: "Senti nosso amor deitado na terra como um monte de cinzas" (nossa tradução). Museu Nacional de Oslo, Noruega. Disponível em: <http://www.nasjonalmuseet.no>. Acesso em 13/02/2019. 
o subjetivismo: "o todo não deve se apresentar como contado, mas como existente" (DÖBLIN, 1989, p. 122 apud FLEISCHER, 2002, p. 148). Nesses textos, aparecem em convivência aspectos feios, macabros e repelentes em motivos grotescos e deformadores.

Assim, no âmbito literário, a estética expressionista transmuta-se em um sentido libertador da escrita em relação à representação latente da realidade, esforçando-se por expressar o indizível, o que não pode ser dito, numa espécie de escrita intervalar, que registra e evidencia em sua pena o modo fragmentário de exposição:

Esse espaço construtor de ideias e de efeitos criativos põe em cena o caráter de fracasso da unidade, da incompletude do simbólico que não recobre todo o real, enfatiza o fragmentário e se vincula à ideia de não excluir a tragicidade da condição humana. (FRANÇA, 2002, p. 130)

A convergência desses procedimentos é capaz de criar uma instabilidade no interior dos romances, visível no caráter revelador da linguagem que expressa uma radicalidade expressiva. Do mesmo modo como o discurso sobre o mundo pode diferir do próprio mundo, apresentando contradições, a linguagem opera com o trabalho incessante do retorno da língua sobre si mesma, favorecendo o ato criativo da escrita: "Esse retorno trabalha na provocação da estranheza, evidenciando o fragmentário, a estranheza própria da língua: unidade perdida mas sempre a ser reconstruída [...]" (Ibid., p. 132).

É preciso reconhecer a escolha da inverossimilhança como um enfoque moderno de indeterminação e deformação dos seres e das coisas. Essa proposta estética alude ao que Roland Barthes (2004) concebe como fundamento de uma nova verossimilhança, que "forma a estética de todas as obras correntes da modernidade" (Ibid., p. 190). Ao comentar o barômetro descrito por Gustave Flaubert em Un coeur simple e a aparente insignificante batida à pequena porta em um dos volumes de Histoire de France, de Jules Michelet, Barthes apresenta-nos os chamados "enchimentos" ou "catálises" como elementos portadores de valores funcionais indiretos. Para o estudioso, tais notações, chamadas por ele ironicamente de "pormenores inúteis", conotam, no entanto, valores simbólicos indiscutíveis às narrativas e são 
passíveis de análise: "[...] tudo, na narrativa, seria significante, e senão, se subsistem no sintagma narrativo alguns intervalos insignificantes, qual é, definitivamente, se assim se pode dizer, a significação dessa insignificância?" (Ibid., p. 184). A partir da formulação barthesiana, é possível pensar nos romances de natureza expressionista, em que estas notações comparecem desalinhavadas, de modo a favorecer o embate entre a causalidade e os dramas pessoais dos personagens. Nesse jogo, singularidades da vida cotidiana misturam-se a subjetividades latentes e em crise, invadidas por movimentos externos obscuros. Como esclarece Barthes:

Essa nova verossimilhança é muito diferente da antiga, pois não é nem o respeito das "leis do gênero" nem sequer a sua máscara, mas procede da intenção de alterar a natureza tripartida do signo para fazer da notação o simples encontro de um objeto e de sua expressão. (Ibid., p. 190)

É uma forma de representar análoga à esfera moderna de indeterminação e deformação, que marca a escrita de Clarice Lispector em O lustre. Conforme tentaremos demonstrar, o enredo desenvolve-se no mundo opaco e silencioso de Virgínia, onde tudo é estático e carente de transformação. Guiando-se pela obscuridade, as sequências temporais alternadas no campo e na cidade embaralham a vida secreta da personagem, que, alheia aos dois ambientes, se acomoda a uma existência sombria e silenciosa. Conforme notou Berta Waldman: "entre a palavra e o silêncio, entre o que diz e o que está implícito em seu dizer, situa-se o texto de Clarice. Ler o seu texto é penetrar nesse âmbito elétrico onde forças opostas se digladiam" (WALDMAN, 1983, p.89).

Tais ideias afinam-se com a argumentação do crítico Anatol Rosenfeld no ensaio "Reflexões sobre o romance moderno" (1985). Segundo Rosenfeld, haveria nas artes plásticas, mais especificamente na pintura do início do século XX, um procedimento de dersrealização, que corresponderia à renúncia do mimetismo. Nesse sentido, a realidade empírica deixaria de ser procurada pela corrente figurativa expressionista: "esta, [realidade empírica] no expressionismo, é apenas 'usada' para facilitar a expressão de emoções e visões subjetivas que lhe deformam a aparência" (ROSENFELD, 1985, p. 76).

Adesrealização empreendidana pintura encontra ressonânciasnasnarrativas, uma vez que o romance não mais apresenta linearidade e descrições 
circunstanciadas, já que o real empírico é apagado junto da cronologia. Desta forma, as ações das personagens abandonam a lógica linear, assentando-se nos aspectos interiores dos seres, à deriva.

O procedimento de desrealização proposto por Anatol Rosenfeld e as discussões em torno da arte expressionista foram fundamentais para a análise de $O$ lustre, de Clarice Lispector. Através da história de Virgínia, o conto centra-se na linguagem e seus aspectos fronteiriços, na medida em que focaliza a protagonista num constante estado de solidão e fuga, o que muito se alinha à estética expressionista.

A consciência do aspecto dinâmico da língua sempre marcou as preocupações de Clarice Lispector em relação à linguagem. Nesse âmbito, perpassam pela literatura clariciana as inquietações em torno da forma e do conteúdo, que catalisam tensões e questionamentos elaboradospela escritora. Tais questões são explicitadas em algumas ocasiões, como se pode notar na famosa conferência Literatura de vanguarda no Brasil, texto de caráter ensaístico, de 1963 e apresentado diversas vezes pela autora: "E essa expressão 'formafundo' sempre me desagradou vitalmente - assim como me incomoda a divisão 'corpo-alma', 'matéria-energia', etc." (LISPECTOR, 2005, p. 98). O mesmo assunto é abordado em crônica publicada no Jornal do Brasil: "[...] a luta entre a forma e o conteúdo está no próprio pensamento: o conteúdo luta por se formar. Para falar a verdade, não se pode pensar num conteúdo sem sua forma" (LISPECTOR, 1999a, p. 254-255). Para Clarice parece haver, portanto, certo descompasso na divisão entre forma e conteúdo, já que, na sua criação estético-literária, tais elementos estão intimamente ligados, em operação recíproca. Assim, a forma responderá a uma determinada configuração quando o pensamento já estiver pronto e articulado: "A dificuldade de forma está no próprio constituir-se do conteúdo, no próprio pensar ou sentir, que não saberiam existir sem sua forma adequada e às vezes única" (/bid., p. 255). Resta à escrita o trabalho da intuição, responsável por agregar de modo sistemático, porém, inconsciente, a forma e o conteúdo: "A intuição é a funda reflexão inconsciente que prescinde de forma enquanto ela própria, antes de subir à tona, se trabalha" (/bid., p. 255). Isso vale para o conceito de vanguarda, discutido pela autora na referida conferência:

Estou chamando o nosso progressivo autoconhecimento de vanguarda. Estou chamando de vanguarda "pensarmos" a nossa língua. Nossa língua ainda não 
foi profundamente trabalhada pelo pensamento. "Pensar" a língua portuguesa do Brasil significa pensar sociologicamente, psicologicamente, filosoficamente, linguisticamente sobre nós mesmos. (Ibid., p. 105-106)

Os dizeres acima trazem a significação de vanguarda como "autoconhecimento" decorrente do fundo, ou seja, do pensamento que surge em comunhão com a forma. Pela relação assentada nessa dinâmica, o conceito decorre de algo genuinamente brasileiro, ampliado sobremaneira pelas fronteiras sociais, psicológicas, filosóficas e linguísticas. Desse modo, a língua, pensada emsua imanência "[...] implica otrabalho do escritor enquanto pessoa e esse trabalho exige, por seu turno, uma entrega incondicional - só assim a literatura pode libertamente ser fonte de conhecimento" (SOUSA, 2011, p. 99).

É nessa atmosfera de tomada de consciência que Clarice Lispector produz suas narrativas, de acordo com as observações feitas sobre a linguagem de suas personagens e a autonomia de suas obras. No que tange à escrita de $O$ lustre, salientamos o papel do foco narrativo em terceira pessoa, responsável pela construção e artefato da personagem; ao mesmo tempo em que isso revela ao leitor seu mundo interior dilacerado e desconexo, traduzido pela reprodução de pensamentos fragmentados, une fatos do passado ao presente da protagonista, somando algumas alucinações. Conforme observou Luiz Costa Lima: "a linguagem da autora de $O$ lustre contém como que uma armadilha: sua simplicidade enganosa, podendo dar ao leitor a impressão de uma planura sem fim, de uma superfície horizontal" (1970, p. 425).

Tais argumentos foram decisivos para o encaminhamento desta pesquisa, que busca apresentar traços diferenciadores de $O$ lustre no arco da produção clariciana, sobretudo quanto às imagens distorcidas do pensamento da protagonista Virgínia, pois evocam os projetos do Expressionismo. A obra em questão, objeto desta análise, espelha o insulamento e a solidão de um sujeito em constante procura pela sua identidade.

Em face desse conjunto de questões, é viável justificar que a metodologia deste trabalho tem como premissa a leitura e análise do romance, observando suas afinidades com o Expressionismo. Feitas estas considerações iniciais, passaremos agora ao exame da obra $O$ lustre, de Clarice Lispector. 


\section{escombros de interioridade}

A narrativa de $O$ lustre aborda a história de Virgínia, desde sua infância na propriedade rural de Granja Quieta, vilarejo de Brejo Alto, até sua maturidade e ida para a cidade grande, onde morrerá tragicamente por atropelamento. Na obra, a trajetória da protagonista é traçada pelos deslocamentos espaciais entre o campo e a cidade e sua inadaptação a qualquer um destes lugares.

A família de Virgínia é composta pelos irmãos Daniel e Esmeralda, os pais e a avó. Com Daniel, Virgínia vive uma estranha relação, pautada por um misto de submissão e admiração. O irmão é o criador da Sociedade das Sombras, brincadeira provinda de um pacto e sediada ao mesmo tempo na mata e no porão da casa, com o objetivo de percorrer o campo e atingir a solidão das trevas da noite, entre outros. Tal pacto surge logo na cena inicial, construída em torno da sugestão de um afogamento, uma vez que Virgínia e Daniel contemplam do alto de uma ponte um chapéu marrom arrastado pela correnteza do rio e decidem calar-se a respeito, pactuando um segredo. Desse modo, inicia-se um processo vertiginoso vivido pela personagem, que, debruçada sobre a ponte, experimenta toda sorte de inquietações e deformações de sentimentos e visões:

Sacudiu-se do sono em que deslizara, os olhos ganharam uma vida perspicaz e cintilante, exclamações contidas doíam no seu peito estreito; a incompreensão árdua e asfixiada precipitava seu coração no escuro da noite. Não quero que a coruja pie, gritou-se num soluço sem som. E a coruja imediatamente piou negro num galho. Sobressaltou-se - ou piara antes de seu pensamento? ou no mesmo instante? Não quero ouvir as árvores, dizia-se tateando dentro de si própria, avançando estupefata. $E$ as árvores a um súbito vento mexiam-se num rumor vagaroso de vida estranha e alta. (LISPECTOR, 1999b, p. 9)

A estética expressionista reflete o estado de insatisfação, de solidão do sujeito diante do mundo e é por meio de afinidades com essa corrente de vanguarda que, na passagem acima, os devaneios de Virgínia são apresentados de modo que as imagens distorcidas venham à tona. Seus pensamentos decorrem do desejo de transcender os limites de sua vida solitária. Para Virgínia, não há saída no meio rural e nem mesmo no meio urbano, quando passa a viver na 
cidade grande. Assim, a técnica do fluxo de consciência desvela e aprofunda a personagem em seu íntimo, inserindo-a em solidão extrema.

Destarte, tanto o sentido da realidade quanto a percepção e constituição do sujeito passam a ser questionados. Aqui estaria um dos aspectos da desrealização abordada por Rosenfeld (1985, p. 85): "Nesse processo de desmascaramento foi envolvido também o ser humano. Eliminado ou deformado na pintura, também se fragmenta e decompõe no romance".

Dilacerada em seu próprio meio, Virgínia vive em choque, observando a decadência de sua família através da visão de um lustre, objeto que dá título à obra e representa o que restara do passado glorioso de outros tempos, na grande sala vazia e decadente do casarão de Granja Quieta. O olhar de Virgínia é o filtro desencadeador de imagens com marcas expressionistas, exibidas pelo seu modo de ver e sentir o mundo. O olhar da personagem traz as distorções do exterior, localizado em meio a um cenário solitário de móveis e objetos degradados:

A própria sala de jantar, o aposento maior do casarão, estendia-se embaixo em longas sombras úmidas, quase deserta: a pesada mesa de carvalho, as cadeiras leves e douradas de uma mobília antiga, uma estante de finas pernas recurvas, o ar rápido nos trincos lustrosos, e um guarda-louça comprido onde translucidamente brilhavam em gritos abafados alguns vidros e cristais adormecidos em poeira. Sobre a prateleira desse móvel pousava a bacia de louça rosada, a água fria na penumbra refrescando a bacia onde se debatia preso um anjo gordo, torto e sensual. (LISPECTOR, 1999b, p. 14-15)

Bastante deformada, a cena sobrepõe brilho e poeira, divindade e sensualidade, peso e leveza, luzes e sombras. Em meio à luminosidade do lustre, ocorrem a vivência e a aprendizagem da morte por Virgínia: "prendendo em si a luminosa transparência alucinada o lustre pela primeira vez todo aceso na sua pálida e frígida orgia - imóvel na noite que corria com o trem atrás do vidro" (Ibid., p. 208).

As imagens da sala de jantar refletem um estado de insatisfação e angústia da personagem diante do mundo, partindo de imagens grotescas. Vale ressaltar que o teórico Wolfgang Kayser (1986) concebe a categoria do grotesco por meio do amálgama da desproporção e do hibridismo. Em seus estudos, 
essa estética surge como uma das formas mais enigmáticas no domínio do "elemento demoníaco do mundo" (Ibid., p. 161).

Kayser atenta para a definição de grotesco, muitas vezes utilizada em sentido semelhante a "arabesco", este último apresentando uma significação ligada à ornamentação. É por meio das formulações do poeta Friedrich Schlegel, mais especificamente em Conversa sobre a poesia (1800), que ocorre a cisão mais delimitada entre os dois termos. Para o teórico, as reflexões de Schlegel surgem como contribuições estéticas basilares do Romantismo e da conceituação de grotesco: "[...] é o contraste pronunciado entre forma e matéria (assunto), a mistura centrífuga do heterogêneo, a força explosiva do paradoxal, que são ridículos e horripilantes ao mesmo tempo" (/bid., p. 56). Portanto, são as fragilidades do sujeito e suas paixões baixas que passam a ser vistas como partes inerentes a sua natureza. As figuras humanas com partes de animais não fazem senão referências à queda humana a estados bestiais e agônicos. Na arte romântica, o grotesco fomenta o olhar do homem para a percepção de suas polaridades, na medida em que cruza feições puras e imaculadas com fraquezas e vícios. Como traço fundante do Romantismo, o grotesco é retomado pelo Simbolismo e, posteriormente, pelos expressionistas alemães.

O alcance da teoria de Kayser em torno do grotesco lança luzes que interessam diretamente a este artigo, no que tange aos processos de apropriação deste conceito presentes na obra clariciana. Em O lustre, há momentos em que as reflexões de Virgínia realçam o isolamento e o juízo que faz do mundo em que vive como as imagens grotescas de formas mal compostas. Trata-se do trabalho que a personagem realiza na infância com bonecos de barro:

Eram bonecos magrinhos e altos como ela mesma. Minuciosos, ligeiramente desproporcionados, alegres, um pouco surpreendidos - às vezes pareciam um homem coxo rindo! [...]. Observava: mesmo bem acabados eles [os bonecos] eram toscos como se pudessem ainda ser trabalhados. Mas vagamente pensava que nem ela nem ninguém poderia tentar aperfeiçoá-los sem destruir sua linha de nascimento. Era como se eles só pudessem se aperfeiçoar por eles mesmos, se isso fosse possível. (LISPECTOR, 1999b, p. 45-46)

Confeccionados com barro e água, os bonecos congregam formas desproporcionais, assemelhando-se a estados inanimados e inorgânicos, 
reatualizados numa espécie de presente eternizado pela ação da personagem. Na vida adulta, esta ação retornará, pois já vivendo na cidade, Virgínia se depara com o forte desejo de remodelar as formas grotescas, em clara alusão ao caminho regressivo da infância:

Trabalhava numa feliz concentração que emprestava ao seu rosto a antiga transparência nervosa. Os bonecos no entanto continuavam o traço dos erguidos ainda na infância. Grotescos, sérios e imóveis, de linha fina e independente, Virgínia obstinadamente insistia em dizer a mesma coisa sem entendê-la. (Ibid., p. 141)

A cena oferece nítida sensação de estranhamento, o que é próprio das vanguardas do século XX. Sua delicadeza apresenta convergências com a estética expressionista, na medida em que atesta a necessidade de expressão da personagem, que, em sua solidão, molda figuras de barro, guardando consigo emoções desconhecidas. Estas parecem brotar da atividade manual com água e terra, em estreita ligação com a realidade íntima. Com Rosenfeld (1985), diremos que nessa abordagem está também um modo de enxergar o indivíduo na modernidade: instável, dissociado, sempre em processo. É este o personagem que aparece em obras capitais do século $X X$, cujos escritores partilham com Clarice Lispector a sua escrita - Proust, Joyce, Kafka, Beckett, Guimarães Rosa, entre outros.

A passagem exemplifica ainda aspectos levantados por Rosenfeld (1985) quanto à desrealização das narrativas, como a abolição do tempo cronológico e das relações causais, já que na vida interior de Virgínia entrelaçamse passado, presente e futuro. Repleta de digressões, a narrativa de $O$ lustre nos oferece o movimento da memória de Virgínia, cooptando ora o passado remoto na Granja Quieta, ora suas aspirações na cidade com visões deformadas. Reverbera nesse romance um enredo que é imperscrutável - ele se se faz apenas ilusoriamente visível e compreensível ao leitor, já que transcorre quase linearmente traçando o itinerário da protagonista com movimentos que vão do campo à cidade e da infância à maturidade. Porém, o plano discursivo revela-se repetidamente cruzado, demorado e interrompido a todo o momento por reflexões e miragens de Virgínia, com abismos intervalares e situações que atingem o limiar da existência. Este contraponto pode ser observado na seguinte passagem, suficiente para mostrar o aspecto deformativo e a turbulenta relação entre a protagonista e 
o irmão Daniel, que constantemente a ameaçava com uma caixa de aranhas "penugentas e grisalhas":

[...] terminou colando um olho no buraco da caixinha e nada vendo senão movimentos vagarosos na escuridão. Ela dizia:

- Vi, já vi, vi tudo! Ele ria:

- Você seria até menos idiota se não fosse tão idiota.

Um dia a caixinha de aranhas afogou-se na água da chuva que invadiu o esconderijo. Um cheiro agudo, roxo nauseante subia de seu interior. Sofrendo, duro e calmo, Daniel mandou Virgínia jogá-la fora.

- Não, não empurre com os pés. Agarre com as duas mãos e ponha fora.

O olho com que ela espiara as aranhas doía. Durante dias lacrimejara torto, caído e de manhã ela não podia abri-lo até que o calor do sol e de seus próprios movimentos acordava-o. Inchou depois, insensivel e sem sangue. Quando tudo passou, já não era o mesmo, tornara-se imperceptivelmente vesgo e menos vivo, mais lento e úmido, mais amortecido que o outro. E se escondia com uma mão o olho são, via as coisas separadas dos lugares onde pousavam, soltas no espaço com numa assombração.

— Não é que a aranha tenha cuspido em você, você sempre gostou de mentir. $\mathrm{O}$ que aconteceu com teu olho foi idiotice. Você e tia Margarida são feitas de quase nada, um espirro e pronto! vocês ficam cheias de dores, aleijadas, pois morra de uma vez.

Ela sentia na sua voz um certo medo. Não era o receio de ser denunciado, ele sabia que a irmã jamais falaria. Arrependimento? -isso fazia com que ela o amasse com um amor cheio de alegria doída, uma vontade animada de se salvarem os dois, de passearem, o coração brilhante. (LISPECTOR, 1999b, p. 33-34)

Embora longa, a passagem é significativa por corporificar a submissão de Virgínia ao irmão e, ao mesmo tempo, manifestar a convergência de sentimentos contraditórios para a personagem, como medo e amor, "um amor cheio de alegria doída" (Ibid., p. 34). É nessa fímbria de emoções que o ato criativo clariciano reflete a inquietude humana, enlaçando no plano do discurso o elo com a arte expressionista. Inevitável dizer que a tensão conflitiva da cena se opera por intermédio do elemento grotesco. Ademais, convém lembrar as colocações de Kayser a respeito das figuras e animais "preferidos pelo grotesco" (1986, p. 157). Segundo o estudioso, "corujas, 
sapos, aranhas - os animais noturnos e os rastejantes, que vivem em ordens diferentes, inacessíveis ao homem" (Ibid., p. 157) estariam nesse elenco, edificando um jogo imagético e horripilante, desprovido de qualquer racionalidade, numa zona bem próxima da diluição dos limites e fronteiras acerca do humano.

Desse modo, a aranha traz uma nítida configuração grotesca para a cena, materializando contradição e perplexidade durante o movimento de cisão de Virgínia enquanto sujeito3. O olho tornado "vesgo", "lento e úmido" reforça a presença do olhar e da perspectiva deformada, responsável pelo ponto de vista do romance centrado em Virgínia: "[...] se escondia como uma mão o olho são, via as coisas separadas dos lugares onde pousavam, soltas no espaço com numa assombração" (LISPECTOR, 1999b, p. 34). Além da deformação do olho, reafirma-se, portanto, a deformação da própria realidade, metonimicamente representada pelo jogo de escuridão e luminosidade. Conforme notou Regina Pontieri em Clarice Lispector: uma poética do olhar, "o grotesco, além de fraturar, funde realidades tidas como distintas" (PONTIERI, 2001, p. 142)4.

Apartada do restante da família, Virgínia experimenta a vida nos seus enigmas e contratempos. O itinerário narrativo formado pela sucessão de momentos encontra-se polarizado entre as vivências familiares e não familiares. Por

3 A imagem da aranha é aqui retomada pela vez segunda vez. No início do romance, o lustre é comparado ao aracnídeo, propiciando o espanto de Virgínia ao observá-lo: "Havia o lustre. A grande aranha escandescia. Olhava-o imóvel, inquieta, parecia pressentir uma vida terrivel" (LISPECTOR, 1999b, p. 15). Adjetivada ao objeto, a aranha contribui para a configuração de diferentes emoções, imiscuídas a perdas e perspectivas para a personagem, pois o lustre trazia presságios de uma "vida terrivel" e ao mesmo tempo castidade e pureza: "[...] o lustre se espargia em crisântemos e alegria. Outra vez - enquanto ela corria atravessando a sala - ele era uma casta semente" (LISPECTOR, 1999b, p. 15).

4 Nesse estudo, Pontieri investiga, entre outros temas, a presença do grotesco na ficção clariciana, afirmando: "Na ficção de Clarice, como se sabe, é frequente a caracterização grotesca [...] Para compreender-lhe o sentido é preciso, porém, ter em mente o modo como ele se reatualiza em algumas das obras da autora" (PONTIERI, 2001, p. 150). Tal reatualização pode ser pensada como paradigma da escrita moderna da escritora presente em contos como Perdoando Deus, de Felicidade clandestina (1971), em que uma mulher tropeça em um rato morto em pleno calçadão de Copacabana; no célebre romance A paixão segundo G.H. (1964), quando a narradora mergulha no abismo mais profundo de sua existência, ingerindo a "massa branca" de uma barata, entre outras obras. Em todas as narrativas, a conjunção com animais abjetos implica na reflexão trazida à esfera da linguagem, bem como o enfrentamento das personagens com o mais recôndito de si mesmas. 
isso, a autora desloca o plano da ação para a esfera anímica, buscando captar as experiências sensíveis e inteligíveis da personagem. Como observou Gilda de Mello e Souza (1980), o que resta desta escrita é a "visão de míope", pormenorizada pelo apeloa nuancese miríades fragmentárias de informações e vivências. Assim, um corte narrativo mostra Virgínia já morando na cidade, separada do irmão Daniel, que se casara. Na tentativa de adaptar-se ao cenário urbano, procura abrigo na casa das primas "solteironas", Henriqueta e Arlete, que ganhavam a vida como costureiras. Fisicamente opostas ("Henriqueta era alta, corada e lenta. [...] Arlete era pequena, seu rosto afinava-se em agulha atenta e distraída" (LISPECTOR, 1999b, p. 118-119), as duas figuras despertam em Virgínia repulsa e sofrimento, sentimentos configurados a partir da avareza de ambas, pois apesar de contribuir com as despesas, Virgínia passa fome na casa das primas.

O díptico de mulheres liga-se aos signos expressionistas, na medida em que reflete a conjunção bizarra de imagens disformes, produzindo o efeito de desregramento na interioridade de Virgínia:

Mesmo que a fome empalidecesse Virgínia o almoço e o jantar não teriam suas horas transferidas. [...] O café era trazido da cozinha e abafado com um estranho capuz que parecia olhar e sorrir, grosso de poeira. A própria sala de costura cheirava a poeira molhada, a mofo, a fazenda nova e a café com batata-doce fria. Virgínia erguia-se do almoço faminta e enojada, sentia o corpo incontrolável e moço exigir cheio de cólera. No entanto ela envelhecia, perdia as cores e era uma mulher. (lbid., p. 120-121)

Com base na pedra de toque do expressionismo, a cena procura penetrar no que há de mais recôndito nas emoções da personagem, desvelando uma complexidade profunda: "[...] ela envelhecia, perdia as cores e era uma mulher" (Ibid., p. 121). As relações humanas, desprovidas de afeto, estendem-se ao cenário decadente da casa velha e sombria em que vivem as primas, o que não se alia às expectativas que Virgínia nutre pela cidade. Como representação de um mundo pobre e decadente, o espaço é também representação deformada, quase caricatural, aos moldes da estética expressionista. 
Vivenciando momentos de extrema apatia, Virgínia deixará a casa após desentendimento com Arlete, acabando por chamá-la de "cadela mentirosa" (Ibid., p. 122), valendo-se de termos "que eram da Granja, do campo aberto mas não da cidade [...]" (Ibid., p. 123). Desse modo, ao procurar o ajustamento entre a expressão e o conteúdo, o narrador justifica a utilização da palavra "cadela", acrescentando sutileza reveladora aos sentimentos da personagem pela força emotiva e psicológica da deformação.

Tudo colabora para a miséria espiritual de Virgínia, mulher com passado e presente marcados pela decadência e solidão. Além de Daniel, sua segregação estende-se a: a) durante a infância, na relação com o pai, homem autoritário e calado; com a mãe, morosa e submissa; com a irmã Esmeralda, que repete a sina materna; e, por fim, com a avó, encerrada no quarto, sem falar e sem se mexer, semelhante a uma morta-viva, b) e prolonga-se à vida adulta na cidade, no relacionamento com os namorados e no reencontro dos familiares, confirmando a indiferença e o isolamento. Como na cena em que visita Brejo Alto, observando os passos de Daniel:

A rua escura em declive abriu-se para uma nesga de rio luminoso, incolor e frio; todo o lixo de Brejo Alto amontoava-se negro à sua margem; pôs as mãos nos bolsos, franziu os olhos como afrontado pela evidência das coisas. Estava agora num largo de muros altos, calmo e cheio de ar claro como o pátio de um convento. Àquela hora as janelas se fechavam, uma ou outra entreaberta mostrava no parapeito uma almofada não recolhida. Brejo Alto parecia construído de pedra pálida, ferro batido e madeira úmida. As casas inclinavam-se velhas e enegrecidas como depois de um incêndio, as ervas cresciam aos tufos nos telhados inclinados -ele prosseguiu, alisou os cabelos negros, finos e penteados, penetrou no centro comercial; das lojas ainda abertas vinha um sufocante cheiro de lugar sombrio onde andam baratas velhas, cinzentas e vagarosas, um cheiro de celeiro. Dos fios do telégrafo pendiam trapos sujos e papéis. (Ibid., p. 207)

A paisagem grotesca da província oferece uma atmosfera de conflito à narrativa, apresentando, por meio do rastro de Daniel, o estado de confusão interior de Virgínia. Ela viveu toda sua infância em Brejo Alto, mas ainda assim esse espaço ressurge como uma forma desconhecida, suja e estranha, com casas "velhas e enegrecidas", enfim, um "lugar sombrio onde andam baratas velhas" (Ibid., p. 207). Ela passeia pelos enredamentos de Brejo Alto, 
traçando com perplexidade sua espacialidade. Pelo modo de subjetivação da matéria narrada, a cena perfaz o caminho labiríntico de sua própria vida, incapaz de ser alcançada e transcorrida como um pesadelo: "tudo começava a negar-se, tudo guardava suas qualidades de ser, a noite se fechava" (Ibid., p. 245).

Observando-se os cenários e as situações vividas e imaginadas pela protagonista, é possível evidenciar uma semelhança com os temas e tonalidades da arte expressionista, que exibe o aspecto obscuro da alma com suas angústias e fraquezas. É possível dizer que há em $O$ lustre a tentativa de dispersão correspondente à dificuldade de se apreender a realidade sensível:

Dominam as linhas retorcidas, as espirais associando-se à perda de contornos, o oposto da claridade das linhas rígidas e bem marcadas, do definido e dos contornos nítidos, ao ponto de se confundir a alma com o espaço exterior. (SOUSA, 2011, p. 216)

Aprisionada em seu mundo interior, Virgínia retorna à cidade, morrendo atropelada. As marcas expressionistas brotam nas imagens disformes, trazendo novamente o grotesco. Seu corpo encontra-se ao lado do chapéu, em clara regressão às imagens das águas turvas da infância, nas quais incidiam o corpo de um afogado e também um chapéu. $O$ encontro com a morte se dá por meio de adjetivos opacos e negativos:

O rosto empoeirado sob o chapéu ligeiramente deslocado da cabeça parecia obscuro e oprimido por um vago temor. O que sucedia? por que desfalecia todo o seu passado e começava horrivelmente um tempo novo? De súbito começou a transpirar, o estômago encolheu-se numa só onda de enjôo, ela respirava terrivelmente opressa e arquejante - o que lhe sucedia? ou o que ia suceder? (LISPECTOR, 1999b, p. 258)

O passado ecoa como ponto de convergência da morte da protagonista. A cena opera níveis que deflagram a desorientação dos sentidos de Virgínia e de tudo que racionalmente se justifica, atuando como desvio ou ponto de fuga para o encontro de sua subjetividade. As deformações denotam o 
olhar da personagem dirigido a si e ao mundo. Nessa dinâmica, as imagens grotescas são transpassadas pela descontinuidade da narrativa; o fluxo de consciência da protagonista leva o leitor, como uma espécie de cúmplice, ao presente e passado de Virgínia, aos seus devaneios e alucinações. O que está na mente da protagonista não pode e não é visto com clareza, uma vez que os tempos se misturam, sem qualquer distinção. Esse amálgama propicia a fragmentação do discurso e a deformação da realidade, contribuindo para a efetivação da estética expressionista. Reside aí uma das linhas de força da obra clariciana, que "faz da negatividade da experiência humana um território insólito a ser explorado pela linguagem" (ROSENBAUM, 2010, p. 173).

Ora, ao encerrar-se com o trágico atropelamento de Virgínia, o romance põe em xeque questões cruciais para os leitores, justapondo abruptamente o belo e o sublime em uma visão extasiada: "[...] na gelada penumbra nascendo uma nova exatidão; não! não! não era uma sensação decadente! mas desejando obscuramente, obscuramente interromper-se, a dificuldade, a dificuldade que vinha do céu, que vinha" (LISPECTOR, 1999b, p. 258). Esses contrastes conferem um misto de dor e enlevo ao fim da protagonista, na medida em que oferecem negatividade e tensão à narrativa, abalando as expectativas habituais dos leitores.

Logo, segundo essa proposta, o Expressionismo fomenta a incerteza e o anseio humano de estar vivo e imerso num tempo inexorável, capaz de ser medido pela estética literária e a vida que dela provém como imagem singular em constante transformação.

\section{considerações finais}

As reflexões em torno de O lustre, segundo romance de Clarice Lispector, desnudam um quadro plural de uma estética fundamentalmente complexa e enigmática, página da história cultural e literária do século XX, chamada Expressionismo.

Conforme tentamos demonstrar, na narrativa em tela observamos semelhanças quanto ao modo de composição expressionista, sobretudo no que diz respeito à ausência de figuração concreta da personagem Virgínia, 
a fragmentação de seu discurso pelo fluxo de consciência e às deformações de paisagens e pessoas representadas.

Ora, o romance fundamenta-se em uma envergadura bifurcada, em que transitam ao mesmo tempo a realidade referencial e os devaneios de Virgínia. Tais imagens interceptam-se de modo caleidoscópico, favorecendo as oscilações e inquietudes do comportamento de Virgínia ao longo da narrativa.

A escrita de vazios parece propor uma espécie de tensão, oriunda da própria linguagem e acentuada continuamente pela interioridade; o efeito é uma estética de deformação, cujo excesso invade o enredo, deixando-o à deriva. Textualmente, a presença negativa de linguagem truncada em algumas passagens destrói a perspectiva tradicional e realista, retratando movimentos contraditórios, inconstantes e até mesmo ilógicos da consciência de Virgínia. Estes movimentos surgem de modo associativo, quebrando a ordem lógica do discurso. Simulacro de clareza e objetividade, tal linguagem, portanto, excede e transfigura o cotidiano da personagem, provocando a deformação de sua perspectiva ao inflar as mais prosaicas situações:

Magra e suja, as veias do pescoço tremiam longas - ela cantava sem graça, puro som gritando, ultrapassando as coisas nos seus próprios termos. [...] Era assim. E era também de sua qualidade saber imitar choros de bichos, às vezes de bichos que não existiam mas poderiam existir. Eram vozes guardadas, redondas na garganta, uivadas, doídas e bem pequenas. Podia ainda fazer apelos agudos e doces como se animais perdidos. Mas de súbito as coisas se precipitavam numa realidade resistente. (LISPECTOR, 1999b, p. 22)

Como se vê, a motivação principal dos procedimentos expressionistas parece residir em $O$ lustre na manutenção de certa visão grotesca e angustiada da protagonista, visto que corroboram o mal estar diante do mundo. Aqui, o Expressionismo encontra-se ao lado da atuação grotesca. Ambos, como elementos fulcrais da narrativa, a tudo invadem, acompanhando Virgínia em sua trajetória. Nesse labirinto deformado, a protagonista, perambula entre a província e a cidade, buscando a si mesma no encontro simultâneo de vida e morte, escuridão e luz. 
Do circuito da infância em Granja Quieta à fase adulta na cidade, Virgínia presencia a consciência da morte em si, efetivada por atropelamento e antecedida pela visão do lustre na última visita à família e ao casarão. Assim, fenece com sua solidão: "Ah, o lustre. Ela esquecera de olhar o lustre. [...] Pensou que o perdera para sempre. E sem se entender, sentindo um certo vazio no coração, pareceu-lhe ainda que na verdade perdera uma de suas coisas" (LISPECTOR, 1999b, p. 255).

Longe de esgotarmos o tema proposto, buscamos empreender um caminho possível de análise do segundo romance de Clarice Lispector, guiando-nos pela discussão acerca da estética expressionista, ao lado de apontamentos críticos da obra da escritora. De sua pena germinam novas e diferentes formas de sensibilidade esteadas na experimentação de uma escrita enigmática e singular, na qual o leitor dificilmente colherá verdades ou certezas inquestionáveis. 


\section{referências bibliográficas}

BARTHES, R. O efeito de real. In: . O rumor da língua. Trad. Mário Laranjeira. São Paulo: Martins Fontes, 2004. p. 181-190. (Col. Roland Barthes).

BRILL, A. O Expressionismo na pintura. In: . GUINSBURG, J. $O$ expressionismo. São Paulo: Perspectiva, 2002, . p. 389-448.

DOBLIN, Alfred. Schriften zu AsthetikÄsthetik, Poetik und Literatur. Olten/ Freiburg im Breisgau, Walter Verlag, 1989. p. 199-123.

FLEISCHER, M. '"A realidade precisa ser criada por nós'nós": rumos da prosa expressionista alemã. In: GUINSBURG, J. O expressionismo. São Paulo: Perspectiva, 2002, . p. 145-156.

FRANÇA, M. I. A inquietude e o ato criativo: sobre o Expressionismo e a Psicanálisepsicanálise. In: . GUINSBURG, J. O expressionismo. São Paulo: Perspectiva, 2002, . p. 121-144.

KAYSER, Wolfgang. O grotesco: configuração na pintura e na literatura. Trad. J. Guinsburg. São Paulo: Perspectiva, 1986.

COSTA LIMA, L. C. Clarice Lispector. In: . COUTINHO, A. (org.). A literatura no Brasil. Rio de Janeiro: Editorial Sul Americana, 1970, vol. 5, p. 449-472.

LISPECTOR, C. Forma e conteúdo. In: . LISPECTOR, C. A descoberta do mundo. Rio de Janeiro: Rocco, 1999a. p. 254-255.

. Literatura de vanguarda no Brasil. In: MONTERO,

T. ; MANZO, L. (Organizadores.). Clarice Lispector: outros escritos. Rio de Janeiro: Rocco, 2005, p. 95-111.

. O lustre. Rio de Janeiro: Rocco, 1999b.

MELLO e SOUZA, G. de. O vertiginoso relance. In: O baile das quatro artes: exercícios de leitura. São Paulo: Duas Cidades, 1980. p. 79-91.

PONTIERI, R. Clarice Lispector: uma poética do olhar. São Paulo: Ateliê Editorial, 2001. 
ROSENBAUM, Y. A ética na literatura: leitura de Mineirinho, de Clarice Lispector. Revista Estudos Avançados, São Paulo, n. 69, vol. 24, 2010, p. 169182, 2010.

ROSENFELD, A. Reflexões sobre o romance moderno. In: . Texto/ Contexto. 4. ed. São Paulo: Perspectiva, 1985. p. 75-97. (Col. Debates).

SOUSA, C. M. de. Clarice Lispector: figuras da escrita. São Paulo: Instituto Moreira Salles, 2011.

WALDMAN, B. Clarice Lispector. São Paulo: Brasiliense, 1983. (Col. Encanto Radical).

\section{imagem:}

MUNCH, Edvard de. Cinzas. Óleo sobre tela, $120 \mathrm{~cm} \times 141 \mathrm{~cm}$. Galeria Nacional, Oslo, Noruega: 1984. Disponível em <http://www.nasjonalmuseet. no>. Acesso em 13/02/2019. 